ARTIKEL PENELITIAN

\title{
FAKTOR DETERMINAN KEJADIAN STUNTING PADA ANAK USIA SEKOLAH DI KECAMATAN LUBUK KILANGAN KOTA PADANG
}

\author{
Delmi Sulastri \\ Bagian Ilmu Gizi Fakultas Kedokteran Universitas Andalas \\ email : delmisulastri@yahoo.com
}

\begin{abstract}
Abstrak
Pembangunan yang kokoh dimulai dengan peningkatan kualitas sumber daya manusia Untuk itu perlu mempersiapkan sejak dini termasuk pada usia sekolah. Status gizi anak usia sekolah merupakan salah satu indikator kesehatan yang perlu menjadi perhatian. Saat ini angka kekurangan gizi pada usia ini masih menjadi masalah, hal ini terbukti dari tingginya prevalensi stunting di Kota Padang .

Penelitian ini menggunakan desain cross sectional bertujuan untuk mengetahui faktor - faktor yang berhubungan dengan status gizi anak usia sekolah yang. Penelitian dilakukan Kelurahan Bandar Buat Kecamatan Lubuk Kilangan Kota Padang pada anak baru masuk sekolah dasar yang berjumlah 77 orang. Data dikumpulkan dengan menggunakan kuesioner, meliputi karakteristik ibu, pengetahuan gizi, tingkat ekonomi, dan asupan gizi, sedangkan data status gizi dikumpulkan melalui pengukuran tinggi badan dengan menggunakan microtoise Dari penelitian ini ditemukan prevalensi anak pendek (stunting) sebesar $35,1 \%$, sebagian besar ibu memiliki tingkat pendidikan tinggi (61\%). Mayoritas ibu tidak bekerja (84\%), pengetahuan gizi ibu masih rendah (66 \%), lebih banyak berada pada tingkat ekonomi rendah (51\%) Asupan energi lebih banyak yang $<90 \%$ AKG $(71 \%)$, sedangkan asupan protein lebih banyak yang $\geq 90 \%$ AKG. Dari uji statistik ditemukan hubungan yang bermakna antara tingkat pendidikan ibu dan tingkat ekonomi dengan status gizi.

Penelitian dapat disimpulkan bahwa faktor yang mempengaruhi status gizi adalah tingkat pendidikan ibu dan tingkat ekonomi. Untuk itu perlunya perhatian khusus dari pengambil kebijakan masalah gizi kronik pada usia sekolah dan perlunya penelitian lebih lanjut.
\end{abstract}

Kata kunci : status gizi, stunting, asupan makanan

\section{Abstract}

The stable development started from increased human resources quality. For that, important to planning early included at school age child. Base on data TBABS prevalence still high. Nutritional status of school-age children is one of the health indicators that need to be a concern. Currently malnutrition at this age is still a problem, it is evident from the high prevalence of stunting in the city of Padang. 
This study uses cross-sectional design aimed to determine factors - factors associated with nutritional status of school age children. The study was conducted Village Bandar Subdistrict Create Lubuk refined Padang at the new children enter primary school, amounting to 77 people. Data were collected using a questionnaire, including maternal characteristics, nutrition knowledge, level of economic and nutritional intake. While the nutritional status of data collected through the measurement of height by using microtoise

From this research, we found that the prevalence of stunting is $35,1 \%$, more than of mother have high education $(61 \%$. Majority of participant was unworker (84\%), 66\% have less knowledge about nutrition, more than of participant have at low economic grade $(51 \%)$. Consumption of energy more than $<90 \%$ AKG $(71 \%)$, meanwhile consumption of protein more than $\geq 90 \%$ AKG $(96 \%)$. From bivariat statistic test with chi-square found significant correlation between mother's education and economic grade with nutritional status.

We concluded that the factor which correlation with nutritional status are mother's formal education and economic grade. For that, need special attention from decision maker to solve chronic under nutrition at school age student, and need to continued this study.

Key word : Stunting, nutrition status, food consumtion 


\section{PENDAHULUAN}

Indonesia mempunyai masalah gizi yang cukup berat yang ditandai dengan banyaknya kasus gizi kurang pada anak balita, usia masuk sekolah baik pada laki-laki dan perempuan. Masalah gizi pada usia sekolah dapat menyebabkan rendahnya kualiatas tingkat pendidikan, tingginya angka absensi dan tingginya angka putus sekolah. ${ }^{(1)}$

Penelitian yang dilakukan oleh Kodyat (1998) menunjukkan bahwa $57,3 \%$ anak sekolah dasar yang berstatus gizi baik, tidak mengalami gangguan pertumbuhan. Sedangkan sisanya mengalami gangguan partumbuhan tingkat sedang $(31,5 \%)$ dan tingkat kurang $11,2 \%$. Gangguan pertumbuhan pada anak SD ini juga ditemukan dengan prevalensi KEP tertinggi di di Aceh 46,6\% dan Timtim $46,2 \%$ sedangkan provinsi dengan prevalensi terendah adalah Bali(20,6\%), di Yogya $(18,9 \%)$ dan DKI Jakarta $(23 \%)$. Rata - rata prevalensi KEP pada anak sekolah dasar di Indonesia adalah 26,3 $-29,9 \%{ }^{(2)}$

Pemantauan Tinggi Badan Anak Baru Masuk Sekolah merupakan metoda yang baik untuk mengetahui pertumbuhan dan perkembangan fisik karena mudah dilakukan. Menurut data pemantauan Tinggi Badan Anak Baru Sekolah (TBABS) di Sumatera Barat dengan indeks(TB/U), pada tahun 1994 prevalensi anak baru masuk sekolah yang stunting (pendek) adalah 31,9\%, kemudian tahun 1999 prevalensi stunting meningkat menjadi $37,8 \%$. $^{(3)}$. Angka ini terus bertahan pada prevalensi yang cukup tinggi dimana dari hasil riset kesehatan dasar pada tahun 2010, prevalensi stunting pada anak usia sekolah yaitu 35.6 dengan $15.1 \%$ anak dengan status gizi sangat pendek dan $20.5 \%$ pendek. Prevalensi stunting di Sumatera Barat juga tinggi yaitu $36.1 \%$ dengan $11.2 \%$ sangat pendek dan $24.9 \%$ pendek. ${ }^{(4)}$ Berdasarkan laporan Dinas Kesehatan Kota Padang, Lubuk Kilangan merupakan kecamatan dengan prevalensi stunting paling tinggi di Kota Padang yaitu sebesar $49,7 \%{ }^{(5)}$

Kekurangan gizi pada usia sekolah akan mengakibatkan anak menjadi lemah, cepat lelah dan mudah sakit. Oleh karena itu anak-anak seringkali absen serta mengalami kesulitan dalam mengikuti dan memahami pelajaran. Dalam keadaan seperti itu sulit mewujudkan SDM yang sehat, cerdas, aktif, kreatif dan produktif yang mampu berkiprah dan bersaing pada era globalisasi. ${ }^{(6)}$

Masalah gizi dikenal sebagai masalah yang multikomplek. Ditingkat rumah tangga, keadaan gizi dipengaruhi oleh kemampuan rumah tangga menyediakan pangan dalam jumlah dan jenis yang cukup, asuhan gizi ibu dan anak yang dipengaruhi oeh faktor pendidikan dan perilaku, serta keadaan kesehatan anggota rumah tangga. Oleh karena itu penanganan masalah gizi memerlukan pendekatan yang terpadu yang mengarah pada pemberdayaan ekonomi keluarga, peningkatan kemampuan dan keterampilan asuhan gizi keluarga serta peningkatan cakupan dan pelayanan dan kualitas pelayanan kesehatan. ${ }^{(7)}$

Penelitian ini bertujuan untuk melihat factor determinan yang berhubungan dengan kejadian stunting pada anak baru masuk sekolah dasar di kelurahan Bandar Buat kecamatan Lubuk Kilangan. Data ini diharapkan bermanfaat bagi peneliti dan juga instansi terkait yang akan mengambil kebijakan terhadap penanggulangan masalah gizi di daerah penelitian.

\section{METODE PENELITIAN}

Penelitian dengan desain cross sectional study dilakukan di enam 
sekolah dasar yang ada di kelurahan distribusi frekuensi dan analisis bivariat Bandar Buat kecamatan Lubuk dengan menggunakan Chi-Square untuk Kilangan. Sampel adalah murid kelas I melihat hubungan dua variabel.

sekolah dasar dan ibunya yang masingmasing berjumlah 72 orang dengan memperhatikan kriteria inklusi dan ekslusi maka sampel dipilih secara acak dengan metode simplel random

\section{HASIL PENELITIAN}

Kelurahan Bandar Buat merupakan salah satu kelurahan di Kecamatan (a) Kilangan Kota Padang propinsi sampling. Terhadap murid SD Sumatera Barat dengan luas wilayah dilakukan pengukuran tinggi badan $2,87 \mathrm{~km}^{2}$. Secara astronomis kelurahan (TB) menggunakan microtoice dengan ini terletak antara $0^{0} \quad 58$ ' 4" Lintang ketelitian $0,1 \mathrm{~cm}$ dan pada ibunya selatan dan $100^{\circ} 21^{\prime} 11^{\prime}$ " Bujur Timur. dilakukan wawancara tentang faktor- Sebagian besar penduduk beragama faktor yang berhubungan dengan status Islam dengan mata pencaharian petani gizi (tingkat pendidikan, tingkat 5\%, pada sektor industri 16\%, pedagang ekonomi, tingkat pengetahuan tentang $17 \%$, PNS $12 \%$, sopir $7,4 \%$ dan lain gizi dan pekerjaan) dengan panduan lain atau rumah tangga $41 \%$. Kelurahan kuesioner, sedangkan untuk menghitung ini memiliki 1 puskesmas, 5 orang asupan energi dan protein dilakukan dokter. 6 orang bidan, dan 2 orang melalui wawancara menggunakan semi dukun bayi. Sarana pendidikan dasar kuantitatif Food Frequency yang terdapat di Kelurahan terdiridari Quesioner/FFQ, kemudian diolah 6 buah Sekolah Dasar (SD).

memakai nutrisurvey. Status gizi Status gizi pendek (stunting) stunting ditegakkan berdasarkan kriteria yang diperoleh melalui pengukuran tinggi badan apabila berada $<-2 \mathrm{SD}$.

tinggi badan anak dibandingkan umur Data yang diperoleh dianalisis secara $(\mathrm{BB} / \mathrm{U})$ dapat kita lihat pada gambar univariat untuk mendapatkan gambaran dibawah ini.

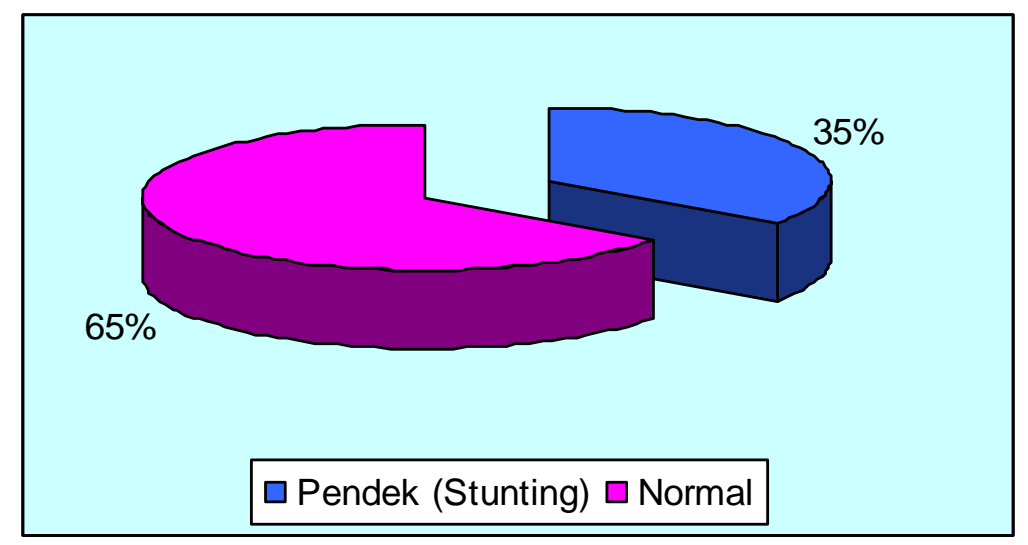

Gambar 1. Sebaran Responden Berdasarkan Kejadian Stunting

Dari gambar 1 dapat dilihat Karakteristik Ibu

bahwa hampir separoh dari responden Karakteristik ibu diukur dari tingkat penelitian menderita kejadian stunting pendidikan, status pekerjaan, tingkat $(35 \%)$. pengetahuan dan status ekonomi. Sebaran responden berdasarkan 
karakteristik ibu dapat dilihat pada Tabel 1.

Tabel 1. Sebaran Responden Berdasarkan Karakteristik (Tingkat Pendidikan, Status Pekerjaan, Tingkat Pengetahuan dan Status Ekonomi)

\begin{tabular}{llll}
\hline \multicolumn{1}{c}{ Variabel } & \multicolumn{1}{c}{ Kategori } & f & \% \\
\hline \multirow{3}{*}{ Tingkat Pendidikan } & Rendah & 30 & 39 \\
& Tinggi & 47 & 61 \\
\multirow{3}{*}{ Status Pekerjaan } & Bekerja & 12 & 16 \\
\multirow{3}{*}{ Tingkat Pengetahuan } & Tidak & 65 & 84 \\
& Rendah & 51 & 66 \\
Status Ekonomi & Tinggi & 26 & 34 \\
& Rendah & 39 & 51 \\
\hline
\end{tabular}

Tabel 1 menunjukkan bahwa lebih dari status ekonomi, lebih dari separoh separoh responden memiliki tingkat responden mempunyai tingkat pendidikan rendah dan sebagian besar pengetahuan dan status ekonomi tidak bekerja. Sedangkan tingkat rendah.

pengetahuan tentang ilmu gizi dan

Tabel 2. Rata - Rata Asupan Zat Gizi

\begin{tabular}{lcccc}
\hline \multicolumn{1}{c}{ Zat Gizi } & Min & Max & Rata-rata & SD \\
\hline Energi (kal) & 1056 & 1991 & 145,32 & 255,08 \\
Protein (gr) & 27,6 & 67 & 43,184 & 8,62 \\
Protein Hewani & 7,28 & 26,42 & 16,99 & 4,62 \\
Protein Nabati & 13,50 & 48,80 & 26,26 & 6,61 \\
\hline
\end{tabular}

Dari Tabel 2 dapat dilihat bahwa rata- kecukupan energi adalah1900 kal/hari rata konsumsi energi masih kurang dari dan protein $37 \mathrm{gr} / \mathrm{hari}$. Sedangkan untuk Angka Kecukupan (AKG) yang asupan protein rata-rata di atas dianjurkan. Kecukupan energi untuk kecukupan gizi yang dianjurkan. Dilihat usia 4 - 6 tahun menurut AKG 1998 dari asupan protein berdasarkan adalah $1700 \mathrm{kal} / \mathrm{hari}$ dan protein 32 sumbernya, protein nabati lebih banyak gram/ hari, dan untuk usia 7 - 9 tahun dibandingkan dengan protein hewani.

\section{Asupan energi}

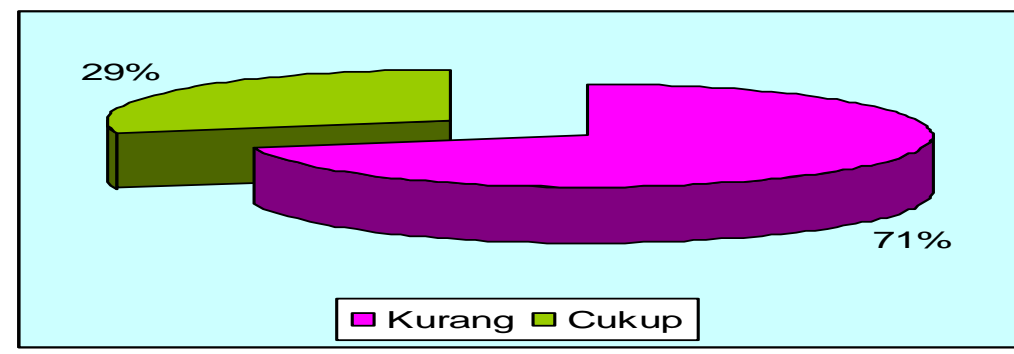

Gambar 2. Distribusi Frekuensi Responden Berdasarkan Asupan Energi 

KOTA PADANG

Dari gambar 2 dapat dilihat bahwa sebagian besar anak memiliki asupan energi kurang $(71 \%)$.

\section{Asupan Protein}

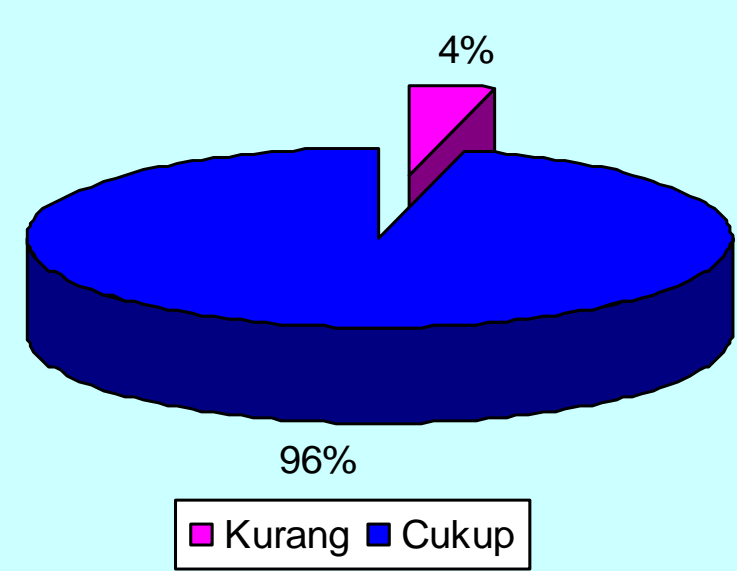

Gambar 3. Distribusi Frekuensi Responden Berdasarkan Asupan Protein

Dari gambar 3 dapat dilihat bahwa umumnya anak memiliki asupan protein cukup (96\%).

\section{Hubungan Tingkat Pendidikan ibu Dengan Kejadian Stunting}

Tabel 3. Hubungan Tingkat Pendidikan Ibu dengan Kejadian Stunting

\begin{tabular}{llccccc}
\hline \multirow{2}{*}{ Variabel } & Kategori & \multicolumn{4}{c}{ Stunting } & P \\
\cline { 3 - 5 } & & \multicolumn{2}{c}{ Ya } & \multicolumn{2}{c}{ Normal } & value \\
\cline { 3 - 5 } & & F & \% & F & \% & \\
\hline \multirow{2}{*}{ Tingkat Pendidikan } & Rendah & 15 & 50 & 15 & 50 & \\
& Tinggi & 12 & 25.5 & 35 & 74.5 & \multirow{2}{*}{0.03} \\
& Bekerja & 2 & 16.7 & 25 & 38.5 & \\
Status Pekerjaan & Tidak Bekerja & 10 & 83.3 & 40 & 61.5 & \multirow{2}{*}{0.15} \\
& Rendah & 21 & 41,2 & 30 & 58,8 & \\
Tingkat & Tinggi & 6 & 23,1 & 20 & 76,9 & 0.12 \\
Pengetahuan & Rendah & 18 & 46,2 & 21 & 53,8 & \\
Status Ekonomi & Tinggi & 9 & 23,7 & 29 & 76,3 & 0.04 \\
\hline
\end{tabular}

Berdasarkan Tabel 3 dapat kita lihat bahwa anak dengan kejadian stunting lebih banyak terdapat pada ibu yang berpendidikan rendah $(50 \%)$, tidak bekerja $(38,5 \%)$ berpengetahuan gizi rendah $(41,2 \%)$ dan tingkat ekonomi rendah $(46,2)$ disbandingkan ibu yang berpendidikan tinggi $(25,5 \%)$, bekerja $(16,7 \%)$, berpengetahuan gizi tinggi $(23,1 \%)$ dengan tingkat ekonomi tinggi $(23,7 \%)$. Hasil uji statistik menunjukkan terdapat hubungan 
yang bermakna antara tingkat Hubungan Asupan Energi dan pendidikan dan status ekonomi Protein Dengan Kejadian Stunting rumah tangga dengan kejadian Pada Tabel 4 dapat dilihat stunting $(\mathrm{p}<0,05)$ besarnya asupan energy dan protein pada anak usia sekolah. Asupan dinilai dengan menggunakan FFQ dan dianalisis memakai nutrisurvey

Tabel 4. Hubungan Asupan Energi dan Protein dengan Kejadian Stunting

\begin{tabular}{rlcccccc}
\hline & & \multicolumn{5}{c}{ Stunting } & \multirow{2}{*}{ Kategori } \\
\cline { 3 - 6 } Variabel & & \multicolumn{3}{c}{ Ya } & Normal & p \\
\cline { 3 - 6 } & & f & \% & f & \% & \\
\hline \multirow{2}{*}{ Asupan Energi } & Kurang & 22 & 40 & 33 & 60 & \\
& Cukup & 5 & 22,7 & 17 & 64,9 & 0.15 \\
& Kurang & 2 & 66,7 & 1 & 33,3 & \\
Asupan Protein & Cukup & 25 & 33,8 & 49 & 66,2 & 0.28 \\
\hline
\end{tabular}

Berdasarkan tabel 4 dapat masih tinggi yaitu 35,1\%. Hasil ini dilihat bahwa anak pendek lebih lebih tinggi dari hasil penelitian yang banyak terjadi pada kelompok anak dilakukan oleh Abas Basuni Jahari dengan asupan energi kurang (40\%) (2001) di Kabupaten Sukabumi Jawa dan asupan protein kurang $(66,7 \%)$ Barat yang menemukan anak pendek dibandingkan kelompok anak atau stunting yaitu sebesar 25,3\%, dan asupan energi dan protein cukup angka ini hampir sama dengan jumlah (22,7\%:66.7\%). Hasil uji statistik prevalensi anak stunting di Indonesia. menunjukkan tidak terdapat Masih terdapatnya anak pendek hubungan yang bermakna antara pada penelitian ini diduga disebabkan asupan energi dan protein dengan karena adanya krisis ekonomi yang kejadian stunting.

\section{PEMBAHASAN}

\section{Status Gizi Anak Stunting}

Status gizi merupakan suatu manifestasi dari keadaan tubuh yang mencerminkan hasil dari setiap makanan yang dikonsumsi. Asupan makanan yang tidak memenuhi kecukupan dalam waktu yang lama melanda Indonesia beberapa waktu yang lalu. Anak baru masuk sekolah pada tahun ajaran 2009 / 2010 adalah anak - anak yang lahir pada tahun tersebut. Sehingga pada masa krisis dapat menyebabkan daya beli

masyarakat untuk pemenuhan kebutuhan makan anaknya menurun yang berdampak terhadap status gizi mereka.

akan mengakibatkan terjadinya Menurut Seotjiningsih (1998), kekurangan gizi yang berdampak adanya faktor lain yang menyebabkan terhadap pertumbuhan anak. Pada terjadinya status gizi pendek (stunting) penelitian ini, status gizi dengan indeks yaitu faktor genetik, penyakit infeksi TB/U dikelompokkan menjadi dua serta pola pengasuhan dan perawatan kategori yaitu pendek (stunting) bila < - ibu terhadap anaknya.

2 SD dan normal bila $\geq-2$ SD.

Pada penelitian ini didapatkan jumlah anak dengan status gizi stunting 
Hubungan Karakteristik Ibu dengan Kejadian Stunting

Hasil penelitian ini menemukan hubungan yang bermakna antara tingkat pendidikan ibu dengan status gizi $(\mathrm{p}<$ 0,05), dimana anak pendek lebih banyak terjadi pada ibu yang berpendidikan rendah.Hasil ini sejalan dengan penelitian yang dilakukan oleh Mulyono (2000) pada bayi yang menunjukkan adanya hubungan yang bermakna antara tingkat pendidikan ibu dengan status gizi anak.

Tingkat pendidikan akan mempengaruhi kesehatan dan kesejahteraan anak, karena hal ini tidak terlepas dari keadaan gizi anak. Ibu dengan tingkat pendidikan yang tinggi akan mempunyai kesempatan yang lebih jelas dalam menyerap informasi jika dibandingkan dengan ibu yang kurang atau tidak berpendidikan. Oleh sebab itu dengan tingkat pendidikan yang cukup diharapkan seorang ibu mau dan mampu untuk berperilaku yang baik dalam rangka memperbaiki keadaan gizi anaknya.

Soekirman (1990) juga menjelaskan bahwa tingkat pendidikan akan mempengaruhi konsumsi pangan melalui cara pemilihan bahan pangan. Orang yang berpendidikan lebih tinggi cenderung untuk memilih bahan makanan yang lebih baik dalam kualitas dan kuantitas hidangan dibandingkan mereka yang berpendidikan rendah atau sedang. Makin tinggi tingkat pendidikan makin baik status gizi anaknya.

Hasil penelitian ini menemukan bahwa tidak terdapat hubungan yang bermakna antara status pekerjaan ibu dengan status gizi ( $p>0,05)$, dimana anak anak pendek lebih banyak terdapat pada ibu yang tidak bekerja dibandingkan dengan ibu yang bekerja.

Hasil ini tidak sejalan dengan penelitian yang dilakukan oleh
Mulyono (2000) pada bayi yang menunjukkan adanya hubungan yang signifikan antara pekerjaan ibu dengan status gizi dimana ibu yang bekerja mempunyai anak pendek $(<-2 \quad \mathrm{SD})$ lebih banyak di bandingkan dengan ibu yang tidak bekerja.

Ibu bekerja yang lebih banyak berada diluar rumah akan memiliki lebih banyak uang untuk dialokasikan atau diinvestasikan kepada anaknya dan sebaliknya makin banyak waktu dirumah bersama anak (makan dan bermain) maka makin kecil kesenggangan waktu untuk mencari nafkah. Kedua hal tersebut (uang dan waktu) akan mempengaruhi kualitas gizi anak

Ibu bekerja diluar rumah, jarak antara rumah dengan tempat kerja dan banyak faktor lain semuanya akan mempengaruhi susunan makan dan pola asuh terhadap anaknya. Sehingga ibu yang tidak bekerja akan mempunyai waktu yang lebih banyak dengan anaknya dan mempengaruhi peningkatan kualitas gizi anaknya. Keadaan tersebut tidak ditemukan pada penelitian ini. Hal ini terjadi karena pada ibu bekerja akan mempengaruhi pendapatan keluarga. Pendapatan yang memadai akan menunjang tumbuh kembang anak, karena orang tua dapat memenuhi semua kebutuhan primer maupun sekunder anak. Sebaliknya pada ibu yang tidak bekerja banyaknya anak pendek disebabkan karena tingkat ekonomi yang rata - rata berada pada tingkat ekonomi rendah, dan rendahnya pengetahuan ibu tentang gizi.

Hasil analisis menunjukkan tidak terdapat hubungan yang bermakna antara pengetahuan dengan status gizi anak $(p>0,05)$, dimana ibu yang pengetahuan gizinya rendah lebih banyak mempunyai anak normal dibandingkan dengan anak pendek. 
Hal ini tidak sejalan dengan hasil penelitian yang didapatkan oleh Sandjaja (2000) pada balita di Kabupaten Sukabumi dan Yogyakarta yang menemukan adanya hubungan yang bermakna antara kedua variabel tersebut.

Pengetahuan gizi merupakan salah satu faktor yang menentukan konsumsi pangan seseorang. Orang yang mempunyai pengetahuan gizi yang baik akan mempunyai kemampuan untuk menerapkan pengetahuan gizi dalam pemilihan dan pengolahan pangan sehingga dapat diharapkan asupan makanannya lebih terjamin

Menurut Soetjiningsih (1998), ibu yang memiliki cukup pengetahuan tentang gizi akan memiliki posisi yang seimbang dalam rumah tangga akan mampu menggunakan alokasi pendapatan rumah tangga untuk memilih pangan yang baik dan mampu memperhatikan gizi yang baik untuk anaknya.

Hal ini tidak sejalan dengan teori yang yang di kemukakan Nasution dan Khomsan yang dikutip oleh Nizar (2000), pengetahuan gizi merupakan landasan penting yang menentukan konsumsi pangan seseorang dan selanjutnya akan mempengaruhi status gizi.

Ketidaksesuaian hasil ini dengan teori disebabkan karena pengetahuan gizi ibu yang tinggi tidak menjamin mempunyai anak dengan status gizi normal.

Menurut Notoatmojo (1993),
faktor lingkungan juga ikut
mempengaruhi seseorang untuk
bertindak. Adanya informasi dari media
massa, keluarga, orang lain dapat
mempengaruhi seseorang dalam ber-
sikap dan bertindak terhadap asupan
makanan.

Hasil analisis menunjukkan terdapat hubungan yang bermakna antara tingkat ekonomi dengan status gizi $(p<0,05)$, dimana anak pendek lebih banyak terdapat pada tingkat ekonomi rendah (maka, dapat dikatakan bahwa anak pendek disebabkan oleh rendahnya tingkat ekonomi).

Hasil ini sejalan dengan penelitian yang dilakukan oleh Ukur Tarigan (2003) pada balita 6- 36 bulan sebelum dan saat krisis ekonomi, yang menunjukkan hubungan yang bermakna antara tingkat ekonomi dengan status gizi. Faktor sosial ekonomi mempengaruhi kemampuan keluarga untuk mencukupi zat gizi anggota keluarganya. Pengaruh ini tidak hanya pada pemilihan macam makanan dan waktu pemberian saja, tetapi juga terhadap kebiasaan hidup sehat dan kualitas sanitasi lingkungan.

\section{Hubungan Asupan Energi dan Protein dengan Kejadian Stunting}

Hasil penelitian ini menemukan tidak adanya hubungan yang bermakna antara asupan energi dengan status gizi ( $p>0,05$ ), dimana pada asupan energi kurang lebih banyak anak status gizi normal dibandingkan dengan yang pendek. (maka, dapat dikatakan bahwa anak pendek bukan disebabkan rendahnya asupan energi).

Hasil ini tidak sesuai dengan teori yang ada bahwa status gizi seseorang sangat ditentukan olah konsumsi zat gizi (energi, protein, karbohidrat, dan lemak) yang berasal dari makanan sehari - hari. Bila tidak terjadi ketidakseimbangan antara asupan zat gizi dengan kebutuhan maka akan terjadi masalah gizi. Konsumsi energi yang rendah dari kebutuhan serta penyakit infeksi merupakan penyebab langsung terjadinya kekurangan gizi.

Terdapatnya hubungan yang tidak bermakna antara asupan energi dengan status gizi, kemungkinan disebabkan adanya faktor-faktor lain 
yang mempengaruhi status gizi seseorang. Faktor tersebut diantaranya adalah aktifitas fisik, riwayat penyakit, kebiasaan jajan, yang pada penelitian ini tidak di teliti.

Hasil penelitian ini menunjukkan hubungan yang tidak bermakna antara asupan protein dengan status gizi $(\mathrm{p}>0,05)$, dimana anak pendek lebih banyak terdapat pada asupan protein kurang (maka, dapat dikatakan bahwa anak pendek belum tentu disebabkan oleh asupan protein yang kurang)

Protein adalah zat gizi penting yang paling erat hubungannya dengan proses - proses kehidupan. Didalam tubuh protein digunakan untuk pertumbuhan dan perbaikan sel - sel. Protein yang cukup akan mampu melakukan fungsinya untuk proses pertumbuhan.

Ketidak sesuaian hasil penelitian ini dengan teori tersebut disebabkan karena berdasarkan rata - rata asupan protein menurut sumbernya, sebagian besar responden lebih banyak mengkonsumsi protein nabati dibandingkan protein hewani.

Protein hewani mempunyai kualitas daya cerna yang tinggi dan termasuk protein sempurna yang memiliki susunan asam amino yang lengkap baik dari segi jumlah maupun jenisnya. Protein sempurna adalah protein yang mampu mendukung pertumbuhan dan pemeliharaan jaringan. Sedangkan protein nabati yang merupakan protein yang tidak sempurna yang tidak memiliki susunan asam amino yang lengkap baik dari segi jumlah dan jenisnya. Jenis protein ini tidak mampu mendukung kesehatan siapapun, karena tidak mampu mengganti jaringan yang rusak, apalagi mendukung pertumbuhan badan. Meskipun dikonsumsi dalam jumlah besar, kualitas protein ini akan dibakar untuk menghasilkan energi dan tidak ada yang dipergunakan untuk sintesa protein tubuh yang diperlukan untuk pertumbuhan maupun pemeliharaan jaringan.

Selain itu, protein dari makanan nabati terlindung dari dinding sel yang terdiri dari selulosa yang tidak dapat dicerna oleh cairan pencernaan tubuh, sehingga daya cerna sumber proptein nabati umumnya lebih rendah dibandingkan protein hewani.

Kemungkinan lain adalah protein yang dikonsumsi digunakan sebagai pengganti energi yang kurang, karena protein adalah salah satu sumber utama energi, bersama - sama dengan karbohidrat dan lemak.

Metoda semi kuantitatif food frekuency Questionre yang dilakukan belum menggambarkan asupan zat gizi yang sebenarnya, karena penilaian asupan makanan dengan metode ini sangat dipengaruhi oleh berbagai faktor seperti daya ingat responden, waktu dan suasana wawancara yang kurang memadai.

\section{KESIMPULAN}

Hampir separoh anak mengalami stunting. Tingkat pendidikan dan tingkat ekonomi merupakan faktor diterminan terhadap kejadian stunting di Kecamatan Lubuk Kilangan Kota Padang.

\section{KEPUSTAKAAN}

1. Hadju, Venny, Metusalach, Darwin Karyadi. Pangan Poternsial unutk Meningkatkan Pertumbuhan Fisik, Daya Pikir dan Produktivitas Serta Mencegah Penyekit Degeratif. Dalam Widya Karya Pangan dan Gizi VI. Jakarta. 1998.

2. DepKes RI. Laporan Pemantauan Status Gizi Anak 
Baru Masuk Sekolah (TBABS). 2004

3. DepKes RI. Laporan Pemantauan Status Gizi Anak Baru Masuk Sekolah (TBABS). 1999.

4. Badan Penelitian dan Pengembangan Kesehatan Kementrian Kesehatan RI. Riset Kesehatan Dasar.hal 40.2010

5. Politeknik Kesehatan RI Padang. Laporan Survey masalah Gizi (SMG) 2002.

6. Notoatmodjo, Soekidjo. Ilmu Kesehatan Masyarakat. Jakarta: Rineka Cipta. 1998.

7. Zairi. Hubungan Pola Pengeluaran RT dengan Status Gizi Balita di Bakb Padang Pariaman (Data Dekunder SMG 2002). Skripsi PSIKM Universitas Andalas. Padang. 2002.

8. Mulyono. Hubungan Status Pekerjaan Ibu dengan Status Gizi Bayi di Kelurahan Lor Kodya Semarang. Tesis IPB. Bogor : 2000 Dikutip dari Info Pangan dan Gizi Direktorat Gizi Masyarakat., Volume XI No. 2, 2000.

9. Soetjiningsih. Tumbuh Kembang Anak. Surabaya: Penerbit Buku Kedokteran. 1998.

10. Mulyono. Hubungan Status Pekerjaan Ibu dengan Status Gizi Bayi di Kelurahan Lor Kodya Semarang. Tesis IPB. Bogor : 2000 Dikutip dari Infi
Pangan dan Gizi Direktorat Gizi Masyarakat., Volume XI No. 2, 2000.

11. DepKes RI. Edaran Tentang KMS Balita dan Pemantauan Status Gizi (PSG) dan Pemantauan Konsumsi Gizi (PKG). Jakarta, 31 Juli 2000.

12. DepKes RI. Rencana Aksi Pangan dan Gizi 2001 - 2005. Jakarta: 2000.

13. Notoatmodjo, Soekidjo. Pengantar pendidikan Kesehatandan Ilmu Perilaku Kesehatan. Yogyakarta: Penerbit Anddi Offset. 1993.

14. Arizal, Sandjaja, Suhartato. Status Gizi dan Kualitas Sumber Daya Manusia Dalam Widya karya Pangan dan Gizi VI. Jakarta. 1998.

15. Sayogya, dkk. Menuju Gizi yang Merata di Pedesaan dan di Kota. Yogyakarta: Gajah Mada University Press. 1994.

16. Ukur Tarigan. Faktor - faktor yang Berhubungan dengan Status Gizi Anak Umur 6 - 36 Bulan Sebelum dan Saat Krisis Ekonomi di Jawa Tengah. Dikutip dari Buletin Penelitian Kesehatan, Volume 21, No. 1, 2003

17. Levin $\quad$ R.J., 1999. Carbohydrates. In Modern Nutrition in Health and Diseases., 9 th edition. Williams \& Wilkins, Philadelphia, London, Toronto, Montreal, Sydney, Tokyo : $49-66$. 
18. Matthews DE. 1999 . Protein. And Amino Acid. In In Modern Nutrition in Health and Diseases, 9 th edition. WB
Saunders

Company,

Philadelphia, London, Toronto, Montreal, Sydney, Tokyo : 11 48. 